\title{
FORMAL AND SEMANTIC DIMENSIONS OF LINGUISTIC DEVELOPMENT: IMPLICATIONS FOR CLASSROOM ENGLISH SECOND LANGUAGE INSTRUCTION IN MULTILINGUAL CONTEXT
}

Felix Banda

University of the Western Cape

The study compares English Second Language (ESL) learners' (Zambian primary, secondary school and tertiary students) intuitions on a number of semantic and grammatical phenomena. Using the Semanticity \& Grammatical Judgement Test, a modified version of the Grammaticality Judgement Test often used by researchers within the Chomskyan tradition (cf. Hyams, 1986; White, 1986; Schachter, 1989), this study investigates the possibility of an accessibility hierarchy ranging from semantic dimensions to formal dimensions of language. The implications of such a hierarchy for the conceptualization of classroom ESL instruction in a multilingual context are discussed. Although Zambia serves as the principal point of reference, there are many elements of relevance to classroom second or third language instruction in South Africa.

Hierdie studie vergelyk Engels Tweede Taal (ETT) leerders (Zambiese primere, sekondere skool en tersiere studente) se intuisies oor verskeie semantiese en grammatikale verskynsels. Deur gebruik te maak van die Semantiese en Grammatikale Oordeel Toets, 'n veranderde uitleg van die Grammatikale Oordeel Toets wat gereeld gebruik word deur navorsers in die Chomskyan tradisie (cf. Hyams, 1986; White, 1986; Schachter, 1989). Die studie doen navorsing oor die moontlikheid van 'n toeganklike hierargie wat wissel van semantiese dimensies tot formele dimensies van taal. Die implikasies van so ' $n$ hierargie vir die begrip van klaskamer ETT onderrig in ' $n$ meertalige konteks word sowel bespreek. Alhoewel Zambie as die vernaamste punt van verwysing dien, is daar elemente van relevansie tot die klaskamer tweede of derde taal instruksie in Suid-Afrika.

\section{THEORETICAL BACKGROUND}

Some research into first language (L1) and second language (L2) acquisition has concluded that every language learner develops his/her own grammar, and such studies have been supported by substantial empirical evidence (see McLaughlin 1987, Ellis 1990 and Larsen-Freeman \& Long 1991, for critiques). Pienemann (1989) takes this argument further in his proposal that instruction has little or no effect on the acquisition of linguistic rules before the learners are developmentally 'ready'. This runs counter to 'common sense' in language teaching circles that language instruction is all about accelerating the rate of acquisition of specified grammatical structures, the success of which can be measured in the learner output. As Ellis (1990) points out, what is taught is not what usually comes out of learners' utterances. In addition, even when the learner's output shows that $\mathrm{s} / \mathrm{he}$ is indeed producing what was taught, this is no guarantee that acquisition has taken place (Lightbown, 1983). This brings into focus the (extent to which early and later language acquisition concerns acquisition of linguistic knowledge, that is morphosyntactic 
knowledge) question about whether early and later language is all about acquisition of linguistic knowledge, which is morphosyntactic knowledge.

Brown (1973) in a study of morphemes, notices that learners used linguistic structures as if they were optional, while Ellis (1984) argues that initially a learner's utterance are devoid of grammar and that they are mere formal realisations of semantic propositions. Furthermore, in his criticism of Widdowson (1975), Ellis (1984: 60) argues that L2 learners' errors are not a result of the learner trying to simplify target language (TL) "code rules" since he does not possess such rules in the first place. A learner rather simplifies semantic propositions that are limited by lexical resources in his/her memory and the context of situation. Ellis (1984:60) concludes: “...it does not make any sense to suggest that the L2 learner simplifies grammatically...[but] reasonable to argue that he simplifies semantically" (Ellis' emphasis). Language research has also shown that language learners are able to use semantic relations and referents in a wide range of communication contexts even before they have acquired the modal aspects of the target language (cf. Fillmore, 1968; Hosenfeld, 1976; Ellis 1984 \& 1990). This could be due to the way linguistic knowledge is represented and related to cognition (Slobin, 1985; Ellis, 1984, 1990; Bialystock $1990,1991)$. Sadock (1991) suggests that semantics makes the least demands on the ultimate (i.e. phonetic) form, while morphology makes more stringent demands on ultimate form than even syntax as seen from the fact that syntactic rules are usually relaxed because of morphological requirements. The implication is that the level of difficulty in processing linguistic knowledge depends, among other things, on how it is represented.

\section{THE STUDY}

We shall assume that there are two types of knowledge, procedural and declarative, (Slobin, 1985; Ellis, 1990; Bialystok, 1990, 1991), and that the two represent independent levels of linguistic representation (Sadock, 1991; Banda, 1992, 1995). Assuming that the dimensions are not necessarily hierarchically related to each other, it is plausible to conclude that a dimension does not necessarily have to wait for the output of the other in order to function (Sadock, 1991). Thus we shall characterise the two types of linguistic representations along the formal and the semantic dimensions. Knowledge represented within the semantic dimension can be said to be aligned to cognition as it is more closely related to the process of conceptualisation, than the intricate forms and modalities of syntax and morphology found in the formal dimension which tend to be sentential or language specific. It has to be noted from the outset that semantic development is not synonymous with cognitive development, although the two could be more closely aligned, than morphosyntactic development and cognitive development. Therefore, the more sentential and language specific a form is, the more difficult it is to process and access it.

In the final analysis, lexical-semantic phenomena can be said to be more easily processed and accessible (by virtue of their close association with the process of conceptualisation and hence to cognition and world view) than syntactic-grammatical phenomena. In essence, this study puts to the test the basic hypotheses posited by Sadock (1991) to the effect that it is easier to process semantic phenomena followed by syntax, free morphology and bound morphology, in that order, because of the way linguistic knowledge is represented. At the same time we are mindful that semantics is related to morphosyntax in as far as collocation regularities that are to do with meanings of lexemes are concerned (cf. Sadock 1991), and that the ultimate objective of grammar is to serve the conveyance of meaning (Cruse, 1986: 2). But as has been argued elsewhere, it is plausible to visualise semantics as independent of morphosyntactic aspects of 
language so that its logical component can be directly specified without recourse to the formal aspects of grammar.

The study reported here uses an approach Cruse (1986) proposes. It is a variation of the contextual approach to language study. Although the approach recognises the relevance of extralinguistic context, it also recognises the possibility of limiting 'context' to linguistic contexts. Moreover, although making a clear-cut distinction between meaning and grammar is difficult, the approach recognises that the two can be disentangled sufficiently for the study of lexical semantics to proceed. The following pair of sentences from Cruse (1986:2) illustrates this point:

1. He harvested a magnetic puff of amnesia.

2. Them yesterday goed home.

Clearly, very few people would dispute that 1 is odd because of its meaning, while 2 is odd because of its deviant grammar.

The study investigated the following research questions:

1. What are L2 learners' intuitions on the semantic dimension of language defined in terms of inappropriateness, paradox and incongruity, and the formal dimension, characterised as syntax, free morphemes and bound morphemes (cf. Cruse, 1986; Sadock, 1991)?

2. Is there a possibility of language acquisition hierarchy ranging from semantic to grammatical knowledge?

3. How can classroom ESL instruction take advantage of learners' differentiated languageprocessing skills regarding formal and semantic dimensions of language (cf. Reber \& Allen, 1978; Reber, 1980; Nation \& McLaughlin, 1986; Sharwood-Smith, 1990; Bialystok, 1990, 1991; Baker, 1996)?

Using data from Zambia's sociolinguistic context, the following specific hypotheses were formulated:

Principle Hypothesis: Given a Semanticity and Grammaticality Judgement Test Zambian ESL learners will find it easy to process knowledge in semantics, followed by syntax, free morphemes and lastly bound morphemes in that order, and thus the following six corollaries can be developed from the principle hypothesis, that is, Zambian ESL learners will perform better on:

Corollary 1: Semantics than on Syntax

Corollary 2: Semantics than on Free Morphemes

Corollary 3: Semantics than on Bound Morphemes

Corollary 4: Syntax than on Free Morphemes

Corollary 5: Syntax than on Bound Morphemes

Corollary 6: Free Morphemes than on Bound Morphemes

\section{METHODOLOGY}

\section{Learning Environment and Description of Subjects}

Since 1968, English has been the official medium of instruction in Zambia from year 1, while seven local languages are designated as subjects to be studied from year 1 in primary school. In 
practice, the teaching of local languages is largely ignored. One reason for this is that passing a local language is not a factor in the selection examination for junior secondary school (at the end of Grade 7), for senior secondary education (at the end of grade 9) or for tertiary level education (at the end of grade 12) (Ministry of Education, 1992: 45). However, in all the above situations, it is obligatory to pass an English examination. In urban areas, both primary and secondary school classes average around 50, but tend to be smaller in rural areas. Generally, secondary school teachers are trained, but according to the Ministry of Education (1992), about $15 \%$ of primary school teachers are untrained. The majority of untrained teachers are found in the rural areas (Williams, 1996). In terms of learning conditions, provision of learning material is generally inadequate; many schools are in need of repair; in rural areas lack of classrooms means classes are held outside; in urban areas, schools have two or three shifts daily in attempt to cope with pupil numbers; there are inadequate book supplies and an inadequate number of desks, with pupils frequently sitting on the floor (Ministry of Education, 1992: 19; Williams 1996).

\section{Subjects}

The subjects of the study were from primary school (at least 7 years formal English instruction); junior secondary school (at least 8 years English instruction); and senior secondary school (at least 10 years formal English instruction), and college (at least 12 years of formal English instruction). The last group were school leavers taking a diploma course in accounting. Most of them were working as Bank Tellers or as Accounts Clerks. Thus, the last group can be said to comprise true school leavers. All the subjects claimed they could speak at least two Zambian languages, apart from English. They were all from Lusaka, the capital city of Zambia, an urban area. Like other urban learners in the former British colonies, these learners must have been exposed to a significant amount of English outside the classroom situation (Banda, 1995, 1996).

Communicative Language Teaching (CLT) is the recommended approach for English language instruction in Zambia. Each of the groups that took part in the study was observed five times (40 minutes/period $\times 5$ ) at different intervals, performing tasks ranging from the "look and say" (cf. Williams, 1996) and English grammar exercises (Grade 7 group), role play and English grammar interventions (Grade 8 and 10 groups), to conducting a job interview and dealing with difficult client situations (college students). From the classroom observations, it was clear that the grade 7 group had more formal instruction aimed at explicit English grammar than secondary school groups (grade 8 and 10). In general the higher the level the less formal instruction aimed at explicit rules was used to supplement the notional/functional communication tasks. College students had no formal instruction aimed at explicit target language rules at all.

\section{Instrumentation}

The deviant sentences used in the study were collected between 1984 and 1994 from primary and secondary school pupils and school leavers through their usual oral and written class work, and personal communication and correspondence with the author outside the classroom and school environment. The deviant sentences were randomly mixed with "correct" ones, and used in the final Semanticity and Grammaticality Judgement Test (see Appendix A). The subjects were required to indicate "Correct" (C), "Incorrect" (IC) or "Not Sure" (NS) if they were unsure about the semanticity and grammaticality of the sentence. In case of IC, subjects were asked to correct or underline the part(s) they thought was/were wrong. This was to ensure that they were rejecting the sentence for the 'right' reason (cf. White, 1986; Banda 1992). Those with NS included those who did not respond. The subjects were specifically asked to concentrate on meaning and grammar. These measures were taken to ensure that "Correct" comprised sentences subjects perceived "acceptable English" in their judgement. 
Their usual teacher of English administered the test to the subjects as in a normal classroom English exercise. The teacher read out each sentence and subjects were then asked to put down their responses. The task was quite fast-paced since the study was intended to get learners' initial intuitions. Also, in previous studies where learners had been given as much time as they wanted, they changed their responses several times (White, 1986). The whole exercise took between 20 and 25 minutes so that there was just enough time for 'slow' learners to 'think' over their responses between the time the teacher read out the sentences and the time learners were required to put down their responses (Banda, 1992).

Two categories of instruments were developed from the test. The first category is related to the Semantic Dimension. The deviances can be said to be due to the meanings/notions and/or clusters of related meanings/notions, making the sentences appear "nonsensical" (cf. sentences 6, 11 and 22) (Cruse, 1986; Sadock, 1991; Banda, 1992, 1995).

The second category of instruments intimates at the Formal Dimension. The deviances in this category are due to the misapplication of allomorphs and/or construction types (cf. sentences, 3 , $5,8,9,12,15,17,20$ and 23). (Slobin, 1985; Cruse, 1986; Banda, 1992, 1995).

That semantics and syntax are closely entwined is recognised and so is the possibility of disentangling the two sufficiently to allow for a study of semantics and morphosyntax (Palmer, 1980; Slobin, 1985; Cruse 1986; Ellis, 1990; Bialystok, 1990, 1991; Banda, 1992). Moreover, that intuition and reasoned argument play a significant role in distinguishing the two phenomena is also recognised. (Cruse, 1986; Sadock, 1991).

Therefore, following Cruse (1986) the deviant sentences were characterised as follows:

\section{The Semantic Dimension}

Inappropriateness: The sentence could be normalised by a cognitive synonym, which readily exists. In other words, the dissonance can be normalised by synonymous substitution. Compare: listen and hear in sentence 6.

Paradox: The dissonance cannot be resolved by synonymous substitution, but there exists a (not too remote) way of resolving the dissonance, e.g., by superordination. Compare sentence 22 whose dissonance is resolved by superordination of the two nouns, which belong to the same family "animal" group.

Incongruity: Neither substitution nor superordination of one semantic element by another will resolve the dissonance. In this regard, the semantic properties have to be reconstructed. Compare sentence 11. The semantic clash between hear and smell cannot be resolved by synonymous substitution or superordination, but by the reconstruction of the "sense" elements of the sentence.

\section{The Formal Dimension}

The formal dimension was categorised as follows:

Syntax: Inversion Rule (sentence 5), Voice (Active) (sentence 8) and Adverbial Rule (sentence 15).

Free morphemes: Overuse of Definite Article 'the' (sentence 3), Number (sentence 17) and Concord (sentence 23) 
Bound morphemes: Omission of Simple Past Tense Marker -ed (sentence 20), Underuse of 3rd Person Marker -s (sentence 9) and Overuse of 3rd Person Marker -s (sentence 12).

Table 1 gives the scores on the test. Considering that "Incorrect" (IC) is the right response in all cases, and one would expect all subjects to select IC in each category. For example, 50 percent (or 17) of the 34 grade 10 learners gave the right answer on the 'Inappropriateness' category by choosing IC.

Results

Table 1 Distribution of Scores in Percentage

\begin{tabular}{lllllllllllll} 
Grade Level & \multicolumn{1}{c}{ Seven $(\mathrm{n}=38)$} & \multicolumn{4}{c}{ Eight $(\mathrm{n}=39)$} & \multicolumn{3}{c}{ Ten $(\mathrm{n}=34)$} & \multicolumn{3}{c}{ College $(\mathrm{n}=38)$} \\
SEMANTICS & C & IC & NS & C & IC & NS & C & IC & NS & C & IC & NS \\
Inappropriateness & 53 & 39 & 8 & 21 & 67 & 13 & 44 & 50 & 6 & 34 & 63 & 3 \\
Incongruity & 21 & 79 & 0 & 31 & 69 & 0 & 24 & 68 & 9 & 3 & 84 & 13 \\
Paradox & 32 & 68 & 0 & 23 & 51 & 26 & 6 & 79 & 15 & 5 & 82 & 13
\end{tabular}

$\begin{array}{lllllllllllll}\text { SYNTAX } & & & & & & & & & & & \\ \text { Inversion } & 24 & 76 & 0 & 31 & 64 & 5 & 26 & 68 & 6 & 11 & 87 & 3 \\ \text { Voice } & 42 & 58 & 0 & 36 & 56 & 8 & 21 & 65 & 15 & 39 & 55 & 5 \\ \text { Adverbial } & 53 & 45 & 3 & 44 & 44 & 13 & 62 & 32 & 6 & 34 & 58 & 8\end{array}$

\begin{tabular}{lllllllllllll}
\multicolumn{2}{l}{ FREE MORPHEMES } & & & & & & & & & & \\
Overuse 'the' & 68 & 32 & 0 & 41 & 51 & 8 & 44 & 47 & 9 & 29 & 66 & 5 \\
Number & 66 & 34 & 0 & 62 & 33 & 5 & 35 & 59 & 6 & 29 & 68 & 3 \\
Concord & 65 & 35 & 0 & 74 & 21 & 5 & 62 & 26 & 12 & 47 & 50 & 3
\end{tabular}

\begin{tabular}{lllllllllllll}
\multicolumn{2}{c}{ BOUND MORPHEMES } & & & & & & & & & & \\
Underuse -s & 76 & 24 & 0 & 82 & 13 & 5 & 65 & 26 & 9 & 63 & 26 & 11 \\
Overuse -s & 66 & 34 & 0 & 62 & 38 & 0 & 65 & 29 & 6 & 34 & 66 & 0 \\
Omission -ed & 84 & 16 & 0 & 82 & 13 & 5 & 74 & 26 & 0 & 39 & 58 & 3
\end{tabular}

Note: Expressed in percentage. IC is the "Correct" response in all cases.

It is clear from the results there were very few subjects who were not sure of their answers as there are comparatively few NS responses. 
Table 2 Matched t-Test showing significant differences

Grade $7(\mathrm{n}=38)$

Matched t-Test

\begin{tabular}{|l|c|c|c|}
\hline Semantics vs. Syntax & .132 & .896 & .3762 \\
\hline Semantics vs. Free Morphemes & .895 & 4.583 & $.0001^{*}$ \\
\hline Semantics vs. Bound Morphemes & 1.184 & 6.716 & $.0001^{*}$ \\
\hline Syntax vs. Free Morphemes & .763 & 4.846 & $.0001^{*}$ \\
\hline Syntax vs. Bound Morphemes & 1.053 & 6.098 & $.0001^{*}$ \\
\hline $\begin{array}{l}\text { Free Morphemes vs. Bound } \\
\text { Morphemes }\end{array}$ & .289 & 1.453 & .1547 \\
\hline
\end{tabular}

Grade $8(\mathrm{n}=39)$

Semantics vs. Syntax

Semantics vs. Free Morphemes

Semantics vs. Bound Morphemes

Syntax vs. Free Morphemes

Syntax vs. Bound Morphemes

Free Morphemes vs.

Morphemes

value Probability

Grade $10(\mathrm{n}=34)$

Semantics vs. Syntax

Semantics vs. Free Morphemes

Semantics vs. Bound Morphemes

Syntax vs. Free Morphemes

Syntax vs. Bound Morphemes

Free Morphemes vs. Bound

Morphemes

\begin{tabular}{|c|c|c|c|}
\multicolumn{2}{c}{ Mean $x-y$} & \multicolumn{1}{c}{$t$ value } & \multicolumn{1}{c}{ Probability } \\
\hline & .308 & 1.67 & .1031 \\
\hline & .897 & 4.81 & $.0001^{*}$ \\
\hline 1.308 & 6.483 & $.0001^{*}$ \\
\hline & .59 & 3.926 & $.0004^{*}$ \\
\hline 1 & 5.676 & $.0001^{*}$ \\
\hline & 1 & 2.396 & $.0216^{*}$ \\
\hline & .41 & & \\
\hline
\end{tabular}

College $(\mathrm{n}=38)$

Mean $x-y \quad t$ value $\quad$ Probability

\begin{tabular}{|l|l|l|l|}
\hline & .147 & .74 & .4643 \\
\hline & .647 & 2.902 & $.0066^{*}$ \\
\hline & 1.147 & 5.91 & $.0001^{*}$ \\
\hline & .5 & 2.405 & $.0219^{*}$ \\
\hline 1 & 1 & 5.05 & $.0001^{*}$ \\
\hline & .5 & 2.511 & $.0171^{*}$ \\
\hline
\end{tabular}

Semantics vs. Syntax

Semantics vs. Free Morphemes

Semantics vs. Bound Morphemes

Syntax vs. Free Morphemes

Syntax vs. Bound Morphemes

Free Morphemes vs. Boun

Morphemes

Probability 2-tail at $(p<0.05)$

* denotes significant difference

\section{SUMMARY OF RESULTS}

- Corollary 1 (Semantics vs. Syntax): Generally the performance is not significant for all groups, though the trend supports the hypotheses.

- Corollary 2 (Semantics vs. Free Morphemes): The difference is statistically different in all the four groups.

- Corollary 3 (Semantics vs. Bound Morphemes): The difference is statistically different in all the four groups. 
Corollary 4 (Syntax vs. Free Morphemes): The difference is significant for grades 7, 8 and 10 , but not for college students.

- Corollary 5 (Syntax vs. Bound Morphemes): The difference is significant for grades 7,8, and 10 , but not for college students.

- Corollary 6 (Free Morphemes vs. Bound Morphemes): The difference is significant for grades 8 and 10 , but not for grade 7 and college students.

It is noteworthy that the differences in corollaries 2 and 3 reach statistical significance in all the groups, while corollaries 4 to 6 do not for the college group - the group made up of school leavers. It is also worthy of note that corollary 6 is not statistically significant for grade $7 \mathrm{~s}$.

The results suggest that learners generally performed better on semantic than on grammatical phenomena. This seems to support the principle hypothesis that language learners find it easier to process semantic phenomena than grammatical phenomena. That is, they were more able to "know" when there was a semantic dissonance than when there was a grammatical deviance. In terms of second language development, the implication is that the stage of semantic development is reached earlier than that of morphosyntactic development.

That the results suggest that the differences in scores on the two dimensions diminish with grade level is also noteworthy. It is as if development on the Formal Dimension is slowly trying to catch up with that on the Semantic Dimension. It is in this light that the non-significant grade 7 and college subjects' scores on corollary 6 should be seen. Grade 7 performed just as poorly on free morphemes as on bound morphemes; while college students performed just as well on the two. In the lower grades, the categories have not developed since knowledge is still more or less undifferentiated. In the intermediate grades, knowledge of free morphemes surpasses that on bound morphemes. In the higher grades and with higher proficiency in ESL, knowledge in bound morphemes develops and comes closer to that in free morphemes. Generally, this appears true of the relationship between the Formal and Semantic Dimensions of linguistic knowledge as conceptualised in this study. The results also suggest that development in the Formal Dimension is still below that on the Semantic Dimension well after 12 years of classroom English instruction.

As a matter of interest, the study revealed the accessibility difficulty categorised as follows:

Level 1: The Semantic Dimension

1. Paradox

2. Incongruity

3. Inappropriateness

Level 2: The Formal Dimension

4. Syntax

5. Free morphology

6. Bound morphology

In essence, subjects had most difficulty with bound morphemes and least difficulty with identifying paradox dissonance. 
Semantic incongruities (e.g. hear vs. smell) and inappropriateness (e.g. listen instead of hear) should not occur in English at all and that such deviances occur is significant. The occurrence could be attributed to the learners Ll interference since in Zambian languages (for example, in Cinyanja) one word 'kumva' can mean listen, hear, or smell. However, this knowledge did not adversely impair the subjects' judgements on the English sentence. In other words, if our results are said to relate to/ reflect second language development, then it can hardly be said that Zambian ESL acquirers process English differently from their first languages.

The discourse-functional hypothesis (Givon, 1979) suggests that learners acquire those structures associated with the type of language use in which they typically participate. Thus, CLT, typically a meaning-focused approach, can be said to account for Zambian learners' superior performance on semantic phenomena. However, the fact that Grade 7 learners, despite explicit doses of grammar, perform poorly on grammar tasks suggests that exposure to formal/planned discourse is a not a sufficient guarantee of proficiency; nor is the opportunity to practice such forms as demonstrated by Grade 8 and 10 learners. The quality of exposure, interaction and input may be more crucial than whether the discourse is planned/formal or unplanned/informal (Ellis, 1990). This could explain why college students, whose instruction and tasks related to "operating conditions" in their places of work, seemed to benefit more from their instruction than the other groups. However, college students' sociolinguistic experience could also explain their superior performance. I will elaborate on this later.

The study also has implications for those working within the Labovian tradition that paying attention to speech engenders proficiency in the target language (cf. Tarone, 1983). The nature of the Semanticity and Grammaticality Judgement Test is such that subjects have to pay attention to the form. Note that subjects were explicitly told to pay attention to grammar and meaning. Clearly, the subjects generally failed to notice deviances from standard morphology, particularly the missing 3rd person $-\mathrm{s}$ and regular past tense -ed markers.

Krashen $(1981,1982,1985)$ emphasises the importance of comprehensible input in interaction. In general, the study suggests it is not just comprehensible input, the quality of the input is also important. College students do not have grammar lessons and yet they outperformed the other groups. Their superior performance particularly on grammar could be due to a richer quality of comprehensible input because of the type of interaction they are involved in, both inside and outside of the classroom. In this regard, sociolinguistic "experience" seemed to have played a part. College students are involved in interactions that necessarily require English use in 'real operating conditions' and their social dispositions in Zambia's ethnolinguistic milieus make them better impression managers (Brown \& Levinson, 1978; Gal, 1979; Rampton, 1987) in English than primary and secondary school learners. Taking this argument further, we can say that college students relatively easy accessing and processing of the Formal Dimension is not because their English grammar hadbecome more permeable (and thus had upset the operations of a Zambian English interlanguage vernacular), but because they have become better manipulators and users of teacherly situations (cf. Gal, 1979; Rampton, 1987). In addition, considering that to progress to tertiary level education in Zambia, one has to pass English examinations, it may be argued college subjects had already proved to be 'good' users of the language. Thus, the college subjects were a biased group. 
In light of the above, college students cannot be said to have turned into excellent users of the 'monitor' all of a sudden. However, this does not place limits on Krashen's Monitor Model and the comprehensible input hypothesis in particular. On the contrary, the fact that college students perform better than primary and secondary school subjects, can be taken as support for Krashen's arguments that speech 'emerges' on its own and that if input is understood and there is enough of it, the necessary grammar is automatically provided. Nevertheless, that the subjects still have problems with what Krashen considers simple rules (e.g. 3rd person -s and regular past -ed markers) suggests that the process of language development is more complex than envisaged in the Monitor Model.

The Multidimensional Model (Meisel, Clahsen \& Pienemann, 1981) on which the teachability hypothesis (Pienemann, 1989) is based posits that the course of linguistic development is constrained by universal factors on the processing abilities of the language learner. The claim is that learners of English will acquire the regular past -ed earlier than 3rd person marker -s. This claim can be tested on our data by looking at underuse and overuse of 3rd person -s with regard to regular past tense marker -ed. The results indicate overuse as less problematic, while underuse as more problematic than the regular past -ed. The suggestion is that the developmental stages of 3rd person -s depend on whether one is referring to underuse or overuse. This finding might sound confusing by appearing to support and disconfirm the postulations of the hypothesis at the same time. The problem, however, is that the multidimensional model does not take into account the fact that the social and psycholinguistic constraints governing when to use a form might be different from those governing when not to use a form. Nevertheless, it is clear even from our study that psycholinguistic factors of some kind play a role in metalingual awareness and language development.

In short, in terms of metalingual awareness and language development, the study suggests a lack of cognitive control of knowledge in as far as morphosyntactic tasks are concerned (Bialystok, 1991, 1992), in comparison with learners' knowledge of semantic learning tasks.

Therefore, that Zambian learners score higher on semantics than on morphosyntactic tasks may be taken as support for the argument that there are two types of linguistic knowledge organised at two levels and that each may have some degree of independence of the other (Sadock, 1991).

\section{CONCLUSION AND IMPLICATIONS FOR CLASSROOM ENGLISH INSTRUCTION IN A MULTILINGUAL CONTEXT}

In the final analysis, if classroom instruction is to follow the learner's natural disposition, then it should be meaning-based, and supplemented by "operating conditions" tasks to make meaningful grammatical forms that are otherwise obscure and inaccessible to learners. Thus, classroom instruction in a multilingual situation should equip the learners with strategies that might help them elaborate on the meanings and forms of English, and thus make them avoid early fossilisation of their IL into English 'vernaculars'. This suggests that instruction should engender creativity in interaction between the learner and significant other, as well as reflect the kinds of interaction one encounters in the real world.

Clearly, CLT has not taken full advantage of the multilingual situation in Zambia. For instance, that Zambian learners already know some lexical items, routines and formulaic patterns in English when they first enter school means that they should be given opportunities to practise 
their English in 'real operating conditions' early in their school life, rather than depending on contrived classroom tasks, even if such tasks were notional/functional communication. In essence, CLT can take advantage of such a situation to make meaningful the structural knowledge contained in the formulas.

Therefore, classroom English instruction should take into account the way learners appear to learn, process and access the L2 in a multilingual context. In this regard, classroom English instruction intervention should aim to promote and reinforce the acquisition of the target language already taking place in the rich multilingual contexts.

Thus, infusion into ESL classroom instruction of aspects of grammar (the formal dimension) should be delayed until learners can meaningfully make sense of the grammatical forms. This suggestion sounds like 'anti-teaching' and goes against language teachers' 'common sense'. However, it appears some grammatical forms are 'unteachable' until well after 10 years of formal classroom instruction in ESL.

It would be interesting to investigate whether a monolingual or bilingual orientation has a differential effect on the processing of semantic and morphosyntactic phenomena in English. In this connection, it would be interesting to investigate whether the results of this study could be replicated in South Africa's different school systems.

\section{REFERENCES}

BAKER, C. 1996. Foundations of bilingual education. Clevedon: Multilingual Matters.

BANDA, F. 1992. On the role of semantics and syntax in classroom second language instruction. Journal of Multilingual and Multicultural Development, 13(4):341-357.

BANDA, F. 1995. The 'Meaning-to-Grammar Hypothesis' of Zambian English: Implications for classroom English instruction in a multilingual context. Unpublished $\mathrm{PhD}$ thesis, Free University Brussels.

BIALYSTOK, E. 1990. Communication strategies: A psychological analysis of second language use. Oxford: Basil Blackwell.

BIALYSTOK, E. 1991. Metalingual dimensions of bilingual proficiency. In Bialystok, E (Ed.) Language processing in bilingual children. Cambridge: Cambridge University Press: 113140

BROWN, P \& S LEVINSON. 1978. Universals in language usage: politeness phenomena. In Good, EN (Ed.), Questions and politeness: Strategies in social interaction. Cambridge: Cambridge University Press: 56-289.

BROWN, R. 1973. A first language: The early stages. Cambridge, Mass.: Harvard University Press.

CRUSE, D. 1986. Lexical semantics. Cambridge: Cambridge University Press. 
CRUSE, D. 1986. Lexical semantics. Cambridge: Cambridge University Press.

ELLIS, R. 1984. Classroom second language development. Oxford: Pergamon.

ELLIS, R. 1990. Instructed second language acquisition. Cambridge, Mass.: Basil Blackwell

FILLMORE, CJ. 1968. The case for case. In Bach, E and R Harms (Eds), Universals in linguistic theory. New York: Holt, Rinehart, \& Winston.

GAL, S. 1979. Language shift. New York: Academic Press.

GIVON, R. 1979. On understanding grammar. New York: Academic Press.

HOSENFELD, C. 1976. Learning about language: discovering our students' strategies. Foreign Language Annals, 9 (2):99-111.

HYAMS, N. 1986. Language acquisition and the theory of parameters. Boston: D. Reidel.

KRASHEN, S. 1981. Second language acquisition. Cambridge: Cambridge University Press.

KRASHEN, S. 1982. Principles and practices in second language acquisition. Oxford: Pergamon.

KRASHEN, S. 1985. The Input Hypothesis: Issues and implications. London: Longman.

LARSEN-FREEMAN, D \& M LONG. (1991) An introduction to second language research. London: Longman.

LIGHTBOWN, P. 1983. Exploring relationships between developmental and instructional sequences in second language acquisition. In Seliger, $\mathrm{H}$ and $\mathrm{M}$ Long (Eds), Classroomoriented research in second language acquisition. Rowley, Mass.: Newbury House: $217-$ 43.

MCLAUGHLIN, B. 1987. Theories of second language learning. Baltimore: Edward Arnold.

MEISEL, J, H CLAHSEN, \& M PIENEMANN. 1981. On determining developmental stages in natural second language acquisition. Studies in Second Language Acquisition (3):109-35.

MINISTRY OF EDUCATION, ZAMBIA. 1992. Focus on learning. Lusaka: Ministry of Education.

NATION, R, \& B MCLAUGHLIN. 1986. Language learning in multilingual subjects: an information processing point of view. In Cook, V. (Ed.) Experimental approaches to second language learning Oxford: Pergamon:41-53.

PALMER, F. 1980. Grammar. New York: Penguin. 
RAMPTON, B. 1987. Stylistic variability and not speaking 'normal' English: some postLabovian approaches and their implications for the study of interlanguage. In Ellis, R (Ed.) Second language acquisition in context. London: Prentice-Hall: 47-58

REBER, AS. 1980. Implicit learning of synthetic languages: the role of instructional set. Experimental Psychology: Human Learning and Memory, (6): 492-502.

REBER, AS. AND R ALLEN. 1978. Analogic and abstraction strategies in syntactic grammar learning: a functional interpretation. Cognition, (6):189-221.

SADOCK, J.M. 1991. Autolexical syntax. Chicago: Chicago University Press.

SCHACTER, J. 1989. Testing a proposed universal. In S. Gass and J. Schachter (Eds.), Linguistic perspectives on second language acquisition. Cambridge: Cambridge University Press:73-88

SCHMIED, J. 1990. Language use, attitudes, performance and sociolinguistic background: a study of English in Kenya, Tanzania, and Zambia. English World-Wide, 11(2):217-38.

SHARWOOD-SMITH, M. 1990. Speaking to minds: on the relevancy of different types of information for the L2 learner. Unpublished Paper: University of Utrecht.

SLOBIN, DI. 1985. Evidence for language capacity. In Slobin, D.I. (ed.) The Crosslinguistic Study of Language Acquisition: Vol. 2: Theoretical Issues. London: Lawrence Erlbaum Associates: 1157-1256).

TARONE, E. 1983. On the variability of interlanguage systems. Applied Linguistics, 4(2):14363.

WHITE, L. 1986. Implications of parametric variation for adult second language acquisition: An investigation of the pro-drop parameter. In Cook, V (Ed.), Experimental approaches to second language learning. Oxford: Pergamon: 55-72

WHITE, L 1989. The adjacency condition on case assignment: do second language learners observe the Subset Principle? In Gass, S and J. Schachter (Eds), Linguistic perspectives on second language acquisition. Cambridge: Cambridge University Press: 134-58.

WIDDOWSON, HG. 1975. The significance of simplification. Studies in Second Language Acquisition, 11(1). University of Indiana Linguistic Club.

WILLIAMS, E. 1996. Reading in two languages at Year 5 in African Primary School. Applied Linguistics, 17(2):182-209.

\section{Biographical Note}

Felix Banda is the Chairperson of the Department of Linguistics at the University of the Western Cape. He has published widely on sociolinguistics and language education. 


\section{Appendix A}

The Semanticity and Grammaticality Judgement Task

1. The dead man was wearing a red shirt.

2. Mr. Phiri is a very good teacher.

3. John goes to school immediately after the breakfast.

4. Mary is the prettiest girl in class.

5. Never I have seen a girl as beautiful as Mary.

6. We hope to listen from you soon.

7. John could not cope with the problem.

8. He very badly painted the house.

9. He has bad breath although he always use tooth paste.

10. John was bitten by a dog.

11. John could hear the smell of the toilet from his room.

12. Mary does not like those people who likes talking while eating.

13. John was punished by his father.

14. Mary has not replied to my letter.

15. Mary works hard in class always.

16. If John went to England, he would study law.

17. John's pen and pencil is missing from his bag.

18. At this school there are more girls than boys.

19. Mary managed to pass her examinations.

20. Mary was suppose to meet us at the football match.

21. Mary was made pregnant by John.

22. Mr. Phiri saw a snake driving to school early in the morning.

23. It is said that there is a lot of diseases in Africa. 